\title{
Use of isotopic tracers to characterize the interaction of water components and nitrate contamination in the arid Rasafeh area (Syria)
}

\author{
A. Al-Charideh · A. Hasan
}

Received: 7 March 2012/ Accepted: 30 October 2012/Published online: 18 November 2012

(C) The Author(s) 2012. This article is published with open access at Springerlink.com

\begin{abstract}
Chemical and isotopic data in atmospheric precipitation, surface water, and groundwater in arid Rasafeh area, northeast Syria, are used to clarify the status of groundwater quality, the interaction of water components, groundwater dating, and vulnerability to anthropogenic contamination. Interpretation of chemical data with thermodynamic calculation reveals that the dissolution of evaporate mineral is the main factor of high salinity. The $\delta^{18} \mathrm{O}$ and $\delta^{2} \mathrm{H}$ relationships indicate that the groundwater is fed by mixing water from Euphrates River and precipitation and the isotope balance equation were used to estimate the contribution of the Euphrates River to the aquifers recharge. High tritium content, together with high ${ }^{14} \mathrm{C}$ activity in the majority of groundwater samples, indicate shorter residence times and consequently potentially greater recharge. The presence of high nitrate concentration associated with high tritium concentration in both shallow and deep aquifer units indicates the presence of high permeability, so that groundwater is highly susceptible to anthropogenic contamination. Nitrate seems to derive exclusively from the application of $\mathrm{N}$ fertilizers. The high nitrate values are characteristic of the areas with intensive agricultural activity, indicating the importance of irrigated return flow on the groundwater.
\end{abstract}

Keywords Environmental isotopes .

Nitrate contamination - Surface water - Groundwater . Rasafeh area $\cdot$ Syria

A. Al-Charideh $(\bowtie) \cdot$ A. Hasan

Department of Geology, Atomic Energy Commission

of Syria (AECS), P.O. Box 6091, Damascus, Syria

e-mail: cscientific@aec.org.sy

\section{Introduction}

Management of water resources has focused on surface water or groundwater as if they were separate bodies. As development of land and water resources increases, it is apparent that evolution dynamics of either of these resources affects the quantity and quality of the other. Nearly all surface water bodies (rivers, lakes, and reservoirs) interact with groundwater (Popov 1979; Popov and Sokolov 1986; Winter et al. 1998; Sophocleous 2002; Jolly et al. 2008). Thus, effective land and water management requires a clear understanding of the linkages between groundwater and surface water as it applies to any given hydrologic setting.

Environmental isotope and geochemical techniques constitute effective tools for solving various problems in hydrology, in particular in the arid and semi-arid regions (Clark and Fritz 1997; Cook and Herczeg 1999; Aggarwal et al. 2005; Mook 2006; Herczeg and Leaney 2010). In such environments, groundwater is a precious resource subject to intensive exploitation for agricultural, urban, and industrial uses. Multi-tracer investigations are commonly applied to understand groundwater movement, mixing patterns between different groundwater sources, salinity origin, recharge period, and such information is needed to improve water-resources management.

The importance of this study comes from the fact that the Rasafeh area represents a specific case of an arid region, where the surface runoff or artificial recharge (Euphrates dam) conditions can enhance water contribution to the subsurface. Therefore, many wells have been drilled for agricultural development project after the construction of Euphrates dam at the end of 1978. The extracted water from these boreholes is used for irrigation and has yielded high production rates of groundwater $\left(50-250 \mathrm{~m}^{3} / \mathrm{h}\right)$. However, 
the water has a salinity of $1,500-6,000 \mathrm{mg} / \mathrm{L}$ TDS, with high $\mathrm{SO}_{4}$ concentration up to $2,000 \mathrm{mg} / \mathrm{L}$ (Fig. 1).

This paper presents the results of a multiple tracer approach $\left(\delta^{18} \mathrm{O}, \delta^{2} \mathrm{H}, \delta^{13} \mathrm{C},{ }^{3} \mathrm{H}\right.$, and ${ }^{14} \mathrm{C}$ as well as the main chemical constituents) to identify the interaction of water components in the arid Rasafeh area, recharge and mechanisms of salinity increase, groundwater residence times, and flow dynamics as influenced by both natural and anthropogenic stresses (i.e., low precipitation rates, high production rates, and agricultural activities).

The investigation methods complement each other and aid in the development of sustainable groundwater management strategies of groundwater after three decades of management work of Euphrates dam in this sector.

\section{Study area description}

The Rasafeh area lies longitude $38^{\circ} 15^{\prime}-39^{\circ} 30^{\prime} \mathrm{E}$ and latitude $35^{\circ} 15^{\prime}-36^{\circ} 00^{\prime} \mathrm{N}$, in the northeastern part of Syria (Fig. 1). The topography of the study area is rather plane. It is generally dominated by flat lands on the right of the Euphrates River with elevation ranging between 300 and
$400 \mathrm{~m}$ a.s.l. (meters above sea level). The climate of the study area is considered to be arid. The long-term average annual precipitation ranges from $150 \mathrm{~mm} /$ year in the south to $207 \mathrm{~mm} /$ year in the north (JICA 1997). Most precipitation occurs from November to March of each year. Another feature characterizing the precipitations in the study area is its irregular yearly distribution. The mean annual air temperature oscillates by $20^{\circ} \mathrm{C}$, and the long-term average annual potential evaporation far exceeds the annual rainfall with a mean annual amount varying from $2,000 \mathrm{~mm}$ in the south to $1,700 \mathrm{~mm}$ in the north (UNDP-FAO 1977).

The permanent surface water is mainly represented by Euphrates River including Euphrates dam reservoir, which is the largest dam in Syria. The reservoir (Assad lack) is a catchment area of $640 \mathrm{~km}^{2}$. The maximum and minimum storage capacity is about $1.41 \times 10^{10}$ and $1.18 \times 10^{10} \mathrm{~m}^{3}$, respectively, corresponding to a water level between 303.93 and $300.40 \mathrm{~m}$ a.s.l. (Fig. 1).

The catchment area of the Euphrates River and its main tributaries are mainly located in Turkey, and thus, approximately $95 \%$ of its flow originates from this country. Most of the river inflows occur between April and June and are caused by the melting of accumulated snows on the

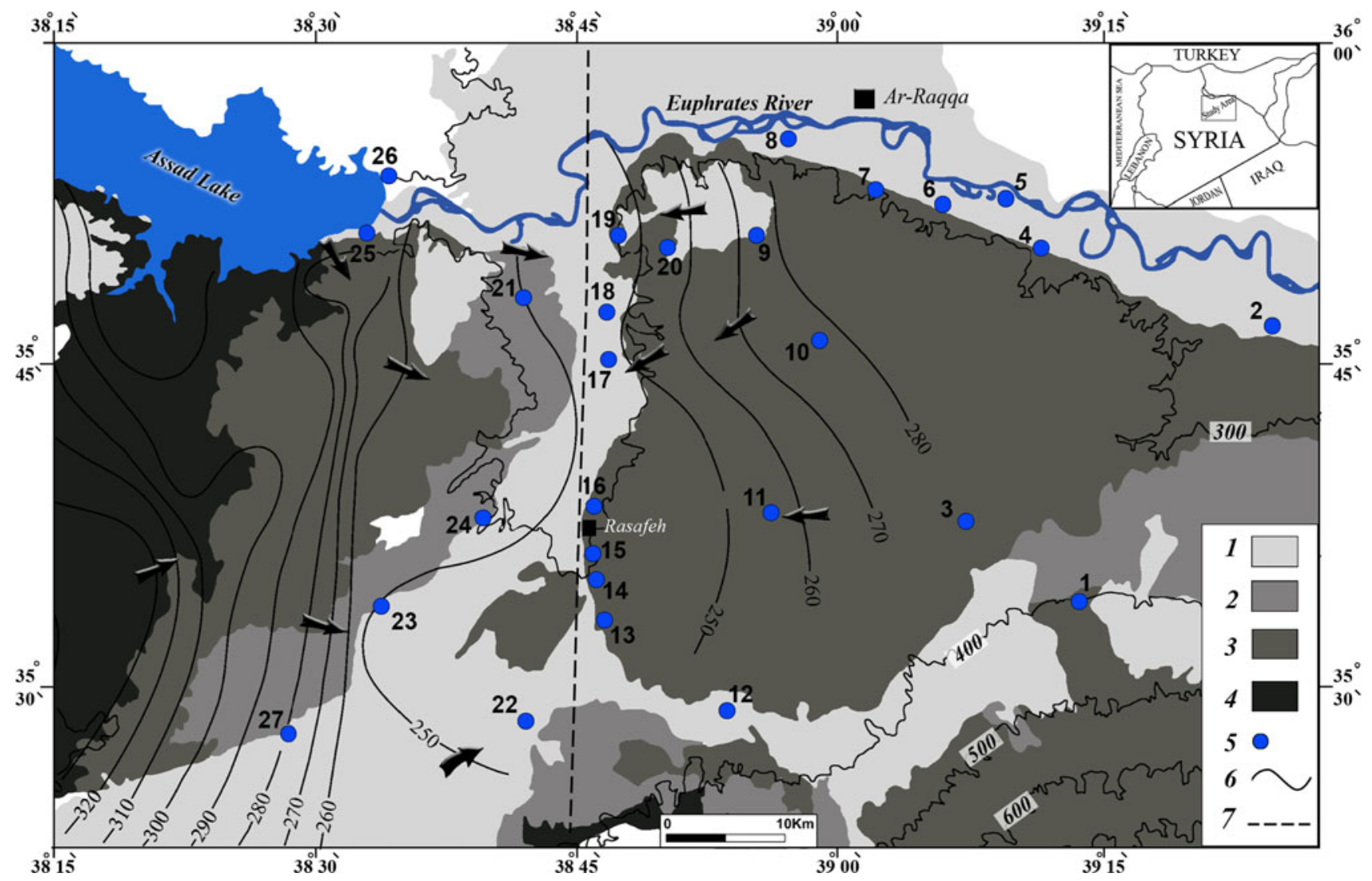

Fig. 1 Geological map of study area: 1 Quaternary (sandy loams, basalt and terrace of Euphrates River); 2 Pliocene (conglomerates, limestone and sandstones); 3 Upper and Middle Miocene (gypsum, marl and limestone); 4 Paleogene (limestone); 5 location of sampling sites of groundwater wells; 6 piezometric level in $\mathrm{m}$ a.s.l. of Upper and Middle Miocene; 7 Rasafeh fault 
highlands $(2,000-3,000 \mathrm{~m})$. The mean annual flow of the Euphrates River at the Syrian-Turkish border (Jarablous station) prior to the 1960s was around $735 \mathrm{~m}^{3} / \mathrm{s}$ (UNDPFAO 1966). During the last few decades, the river flow has been controlled by Turkey, through a treaty that fixes the minimum annual river discharge for both Syria and Iraq at around $500 \mathrm{~m}^{3} / \mathrm{s}$.

Groundwater is the main source of irrigation in the Rasafeh region. No surface water irrigation system exists at the right side of Euphrates River and dam. Most of the agricultural plains in Rasafeh area lie on these sedimentary systems cultivated with cotton and wheat. Significant reductions of groundwater quality accompany the return irrigation water through agricultural fields. The high nitrate concentration in groundwater samples indicates remarkable input from return irrigation water along the Rasafeh fault system, where the agricultural activities are concentrated.

\section{Geology and hydrogeology}

The outcrop rocks in the study area are from Paleogene, Neogene, and Quaternary ages (Fig. 1). The Quaternary formations (total thickness range between 30 and $130 \mathrm{~m}$ ) are of continental origin, and consist of clay silts, sand, gravel, loams, marl, gypsum debris corresponding to Pleistocene and Holocene. Some effusive volcanic rocks of Lower Quaternary age can be seen in the vicinity of the study area.

The Neogene rocks outcrop in the major part of the study area and are represented by the following deposits; Lower Pliocene rocks outcrop mostly in the west of the Rasafeh fault. They usually consist of gray, sandstones or dolomite limestone and marl. The lower parts are more marly and often contain considerable amounts of gypsum. The Middle Miocene rocks, which are generally known as the lower Fars formation (Tortonain $\mathrm{N}_{1}^{\mathrm{t}}$ ) are met with over a large area especially east of the Rasafeh fault. They form the plateau that separates the Miocene Euphrates depression and the north Palmyrides Mountains. The thickness varies from 100 to $600 \mathrm{~m}$ (UNDP-FAO 1977).

These Tortonain rocks are characterized by seams of gypsum stone of variable thickness (from tens of centimeters up to almost $40 \mathrm{~m}$ ) dominating the strata. They also contain marls, clays, limestone, dolomite limestone, sandstones, and silts. The Middle Miocene rocks (Helvetian $\mathrm{N}_{1}^{\mathrm{h}}$ ) also outcrop in the extreme west of the study area and form a cliff above the Euphrates valley by the dam site. These Helvetian rocks consist of dolomite limestone having a chalky structure at their base. The bore logs showed their thickness would appear to range between 40 and $100 \mathrm{~m}$.

The Paleogene rocks of Eocene age outcrop in the extreme west of the study area and contain soft chalk, limestone, and marl (Fig. 1).
The major hydrogeological features of Rasafeh area consist of two aquifers: the shallow unconfined aquifer, with a maximum thickness of $30 \mathrm{~m}$. This aquifer is hosted in the Quaternary rocks over most of the Euphrates valley and its terraces. The width of these deposits along the present path of the Euphrates River is $<3 \mathrm{~km}$ but increases to the south around the Rasafeh fault system (old channel of Balikh River). This aquifer is laterally connected with the water-bearing system of Miocene aquifer (Gersar-Sect 1977). Underlying this aquifer is the so-called deep aquifer system which is related to the Middle Miocene rocks (Tortonain and Helvetian formations) with widely differing extension and thickness. In these gypso-marl or limestone and dolomite rocks, permeability depends mostly on the existence of karst features; the great fractured areas such as the great Rasafeh fault system, the Euphrates rift valleys, dam, and the secondary faults in the old channel of Balikh River are of great importance from a water circulation standpoint (UNDP-FAO 1977). The properties of the two aquifer units are not known within the study area, and the stratigraphic formations around the Rasafeh fault system show that no confining layers (i.e., clay aquitards) exist between the two aquifer units.

Groundwater recharge for both aquifers is mainly controlled by Euphrates infiltration. The piezometric contour map (Fig. 1) is quite regular and this supports the remark that the different permeable beds have a good hydraulic connection. Such interconnection could take place as a consequence of various factors such as the differences in head between the Euphrates dam and groundwater or through fracture zones such as the Rasafeh fault or the Euphrates fracture. The piezometric map shows the groundwater flow system. The groundwater is found at a depth over $200 \mathrm{~m}$ a.s.l around the Rasafeh fault system and at more than $300 \mathrm{~m}$ a.s.l west of the study area. The groundwater aquifer is recharged from the Euphrates River and dam to the south and from the north Palmyrides Mountains (Jabel El-Bichri) to the north.

\section{Sampling and analytical methods}

Monthly precipitation samples were collected during the period 1998-2000 from Ar-Raqqa and Palmyra meteoric stations at 350 and $400 \mathrm{~m}$ a.s.l respectively. These two stations are situated on the south and north of the study area. In the same period, two sites were selected on the Euphrates River and dam, sites Nos. 5 and 26, respectively: site 26 represents the end of the left wing of the dam named Salhabieh canal with $140 \mathrm{~m}^{3} / \mathrm{s}$. Groundwater samples were collected from 25 active pumping wells, ranging in depth from 10 to $300 \mathrm{~m}$ (Fig. 1). Most of these wells have been drilled in the Middle Miocene (Tortonain and Helvetian 
age) and have being used for agriculture after the construction of Euphrates dam at the end of 1978.

Physical and chemical parameters were measured in the field (Table 1): temperature, $\mathrm{pH}$, electrical conductivity (EC), and total alkalinity (i.e., $\mathrm{HCO}_{3}{ }^{-}$). The total dissolved inorganic carbon (TDIC) for 15 samples of groundwater was precipitated in the field from about $120 \mathrm{~L}$ of groundwater using the well-known IAEA procedure (Tamers and Scharpensel 1970). The water samples that were collected from different locations were analyzed for major cations such as $\mathrm{Ca}^{2+}, \mathrm{Mg}^{2+}, \mathrm{Na}^{+}$, and $\mathrm{K}^{+}$and major anions $\mathrm{HCO}_{3}{ }^{-}, \mathrm{SO}_{4}{ }^{2-}, \mathrm{NO}_{3}{ }^{-}$, and $\mathrm{Cl}^{-}$. The chemical analyses of water samples were performed by ion chromatograph method (HPLC) after filtration through $0.45 \mu \mathrm{m}$ at the laboratories of the Syrian Atomic Energy Commission (SAEC). Charge balance calculation showed that charge imbalance did not exceed $\pm 5 \%$ for all the samples.
The environmental tritium, carbon-13 and carbon-14 measurements were carried out to date the groundwater. In addition, the water samples were also subjected to stable isotopic analyses (deuterium and oxygen-18 ratios) to understand the origin, mixing pattern, and evaporation effect. All the measurements of environmental isotopes were performed in the PINSTECH isotope laboratory of Pakistan.

The measurement of $\delta^{18} \mathrm{O}, \delta^{2} \mathrm{H}$, and $\delta^{13} \mathrm{C}$ were performed with a mass spectrometer. The tritium content was determined using the electrolytic enrichment and liquid scintillation counting method (Florkowski 1981). The isotopic contents are reported in conventional $\delta$ notation "per mil" as a deviation from the Vienna Standard Mean Ocean Water (V-SMOW), while carbon isotope ratios are also expressed using the $\delta$-notation in \%o relative to the Vienna Pee Dee Belemnite (V-PDB) standard (Craig 1957; Gonfiantini 1978).

Table 1 Mean chemical composition and field data of surface water and groundwater samples collected from study area

\begin{tabular}{|c|c|c|c|c|c|c|c|c|c|c|c|c|c|c|}
\hline \multirow{2}{*}{$\begin{array}{l}\text { Map } \\
\text { (no.) }\end{array}$} & \multirow{2}{*}{$\begin{array}{l}\text { Depth } \\
(\mathrm{m})\end{array}$} & \multirow{2}{*}{$\begin{array}{l}\mathrm{T} \\
\left({ }^{\circ} \mathrm{C}\right)\end{array}$} & \multirow{2}{*}{$\begin{array}{l}\text { TDS } \\
(\mathrm{mg} / \mathrm{L})\end{array}$} & \multirow{2}{*}{$\begin{array}{l}\mathrm{Ca}^{2+} \\
(\mathrm{mg} / \mathrm{L})\end{array}$} & \multirow{2}{*}{$\begin{array}{l}\mathrm{Mg}^{2+} \\
(\mathrm{mg} / \mathrm{L})\end{array}$} & \multirow{2}{*}{$\begin{array}{l}\mathrm{K}^{+} \\
(\mathrm{mg} / \mathrm{L})\end{array}$} & \multirow{2}{*}{$\begin{array}{l}\mathrm{Na}^{+} \\
(\mathrm{mg} / \mathrm{L})\end{array}$} & \multirow{2}{*}{$\begin{array}{l}\mathrm{HCO}_{3}{ }^{-} \\
(\mathrm{mg} / \mathrm{L})\end{array}$} & \multirow{2}{*}{$\begin{array}{l}\mathrm{Cl}^{-} \\
(\mathrm{mg} / \mathrm{L})\end{array}$} & \multirow{2}{*}{$\begin{array}{l}\mathrm{SO}_{4}^{2-} \\
(\mathrm{mg} / \mathrm{L})\end{array}$} & \multirow{2}{*}{$\begin{array}{l}\mathrm{NO}_{3}{ }^{-} \\
(\mathrm{mg} / \mathrm{L})\end{array}$} & \multicolumn{3}{|l|}{ SI } \\
\hline & & & & & & & & & & & & $\mathrm{Cal}$ & Dol & Gyp \\
\hline 1 & 304 & 28.5 & 2,945 & 600 & 145 & 8 & 25 & 66 & 72 & 1,960 & 69 & 0.89 & 1.43 & -0.01 \\
\hline 2 & 35 & 21.0 & 4,114 & 617 & 250 & 15 & 455 & 153 & 445 & 2,095 & 84 & 0.71 & 1.41 & -0.04 \\
\hline 3 & 240 & 28.0 & 3,748 & 580 & 290 & 11 & 170 & 120 & 210 & 2,212 & 155 & 0.61 & 1.18 & -0.06 \\
\hline 4 & 45 & 20.5 & 5,197 & 650 & 235 & 13 & 780 & 134 & 1,134 & 2,186 & 65 & 0.68 & 1.31 & -0.03 \\
\hline 5 & ER & 20.0 & 349 & 45 & 18 & 3 & 30 & 109 & 25 & 114 & 5 & 0.49 & 1.01 & -1.71 \\
\hline 6 & 23 & 20.0 & 2,707 & 350 & 115 & 7 & 250 & 181 & 275 & 1,480 & 49 & 0.53 & 0.99 & -0.27 \\
\hline 7 & 10 & 19.5 & 3,199 & 550 & 125 & 8 & 233 & 154 & 310 & 1,767 & 52 & 0.82 & 1.44 & -0.06 \\
\hline 8 & 15 & 20.0 & 4,167 & 500 & 215 & 11 & 520 & 229 & 570 & 2,068 & 55 & 0.76 & 0.62 & -0.11 \\
\hline 9 & 280 & 29.4 & 3,094 & 376 & 198 & 20 & 301 & 134 & 479 & 1,556 & 30 & 0.69 & 1.36 & -0.31 \\
\hline 10 & 300 & 28.0 & 3,270 & 474 & 164 & 10 & 310 & 165 & 496 & 1,636 & 15 & 0.55 & 0.93 & -0.18 \\
\hline 11 & 150 & 25.0 & 3,411 & 550 & 225 & 18 & 160 & 94 & 210 & 2,120 & 34 & 0.73 & 1.38 & -0.05 \\
\hline 12 & 225 & 28.5 & 3,342 & 280 & 136 & 21 & 620 & 153 & 1,206 & 916 & 10 & 0.27 & 0.51 & -0.59 \\
\hline 13 & 100 & 24.0 & 4,357 & 528 & 156 & 23 & 680 & 140 & 1,170 & 1,650 & 10 & 0.57 & 0.95 & -0.17 \\
\hline 14 & 174 & 25.0 & 5,054 & 680 & 250 & 20 & 700 & 112 & 1,197 & 2,042 & 53 & 0.63 & 1.17 & -0.05 \\
\hline 15 & 100 & 23.0 & 5,434 & 700 & 238 & 24 & 700 & 101 & 1,400 & 2,173 & 98 & 0.68 & 1.25 & -0.02 \\
\hline 16 & 90 & 22.0 & 5,025 & 600 & 205 & 22 & 750 & 115 & 1,270 & 1,938 & 125 & 0.48 & 0.86 & -0.01 \\
\hline 17 & 80 & 23.0 & 3,464 & 276 & 106 & 13 & 750 & 201 & 1,206 & 882 & 30 & 0.51 & 0.98 & -0.59 \\
\hline 18 & 80 & 23.0 & 3,643 & 320 & 105 & 20 & 820 & 145 & 1,252 & 955 & 26 & 0.22 & 0.33 & -0.52 \\
\hline 19 & 55 & 23.0 & 5,610 & 650 & 210 & 20 & 1,080 & 128 & 1,260 & 2,186 & 76 & 0.69 & 1.25 & -0.05 \\
\hline 20 & 100 & 24.6 & 5,811 & 730 & 215 & 24 & 940 & 131 & 1,607 & 2,108 & 56 & 0.69 & 1.18 & -0.03 \\
\hline 21 & 95 & 23.0 & 3,815 & 276 & 137 & 25 & 826 & 207 & 1,418 & 891 & 35 & 0.68 & 1.42 & -0.62 \\
\hline 22 & 173 & 27.0 & 6,013 & 600 & 225 & 25 & 1,170 & 143 & 1,650 & 2,150 & 50 & 0.92 & 1.71 & -0.11 \\
\hline 23 & 155 & 25.0 & 4,673 & 350 & 180 & 24 & 940 & 179 & 1,794 & 1,191 & 15 & 1.06 & 2.15 & -0.47 \\
\hline 24 & 165 & 24.0 & 4,160 & 320 & 140 & 22 & 820 & 147 & 1,733 & 943 & 35 & 1.14 & 2.27 & -0.56 \\
\hline 25 & 30 & 21.0 & 1,614 & 220 & 124 & 7 & 70 & 256 & 121 & 806 & 10 & 0.79 & 1.73 & -0.61 \\
\hline 26 & ED & 19.0 & 283 & 40 & 12 & 3 & 21 & 158 & 28 & 21 & 0 & 0.133 & 0.188 & -2.42 \\
\hline 27 & 136 & 27.0 & 5,825 & 450 & 235 & 22 & 1,140 & 99 & 2,100 & 1,754 & 25 & 1.07 & 2.15 & -0.28 \\
\hline
\end{tabular}

SI values are saturation index for calcite, dolomite and gypsum calculated by geochemical code NETPATH 2.0 (Plummer et al. 1994)

$E R$ Euphrates River, ED Euphrates dam 
Analytical accuracy of $\delta^{2} \mathrm{H}, \delta^{18} \mathrm{O}$, and $\delta^{13} \mathrm{C}$ is $\pm 2, \pm 0.2$, and $\pm 0.2 \%$, respectively. The results of ${ }^{3} \mathrm{H}$ are expressed in tritium units (TU) (one TU is equivalent to one ${ }^{3} \mathrm{H}$ atom per $10^{18}$ atoms of hydrogen). Error on tritium measurement is $\pm 0.7 \mathrm{TU}$. The results of ${ }^{14} \mathrm{C}$ are reported in percent modern carbon (pmc); the degree of uncertainty depends on the quantity of analyzed material, the counting time, and the activity of the sample.

\section{Results and discussion}

\section{Water chemistry}

The total dissolved solids (TDS) in the groundwater samples are varied between 1,614 and $5,800 \mathrm{mg} / \mathrm{L}$ for a temperature ranging from 21.0 to $29.4{ }^{\circ} \mathrm{C}$ (Table 1). The groundwater samples are well oxygenated, with $\mathrm{pH}$ values in the range 7.4-8.0, and are significantly more mineralized than the Euphrates River.

The piper diagram (Fig. 2) shows the relative concentration of the different ions from individual water samples. Two main groundwater types have been identified based on major ions concentrations: $\mathrm{Ca}-\mathrm{SO}_{4}$ and $\mathrm{Na}-\mathrm{Cl}$, while in the Euphrates water, the TDS are from 280 to $350 \mathrm{mg} / \mathrm{L}$ for a temperature ranging from 19 to $20^{\circ} \mathrm{C}$ and $\mathrm{Ca}-\mathrm{HCO}_{3}$ water type. Nitrate concentrations in groundwater were highly variable in space, both along the horizontal and vertical directions, in the Rasafeh area.

The $\mathrm{NO}_{3}$ concentration values were not significantly different between the shallow and deep wells of the Rasafeh area (20 and $155 \mathrm{mg} / \mathrm{L}$ ); however, higher nitrate concentrations are observed in the groundwater wells along

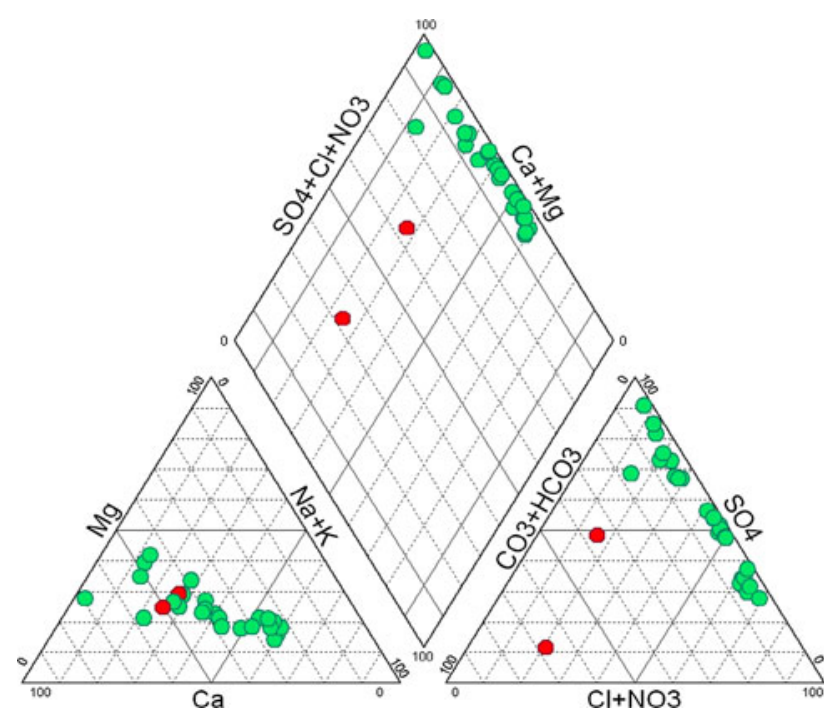

Fig. 2 Piper diagram of the chemical composition of surface water (red circles) and groundwater (green circles) of the study area the Rasafeh fault system where the development associated with the excessive use of fertilizers is the principal source of nitrates contamination from the return irrigated water (Smith et al. 1991; Wassenaar 1995).

The values of $\mathrm{NO}_{3}$ concentration in the Euphrates River and dam reservoir (sites Nos. 5 and 26) are 2 and $5 \mathrm{mg} / \mathrm{L}$, respectively (Table 1). The spatial distribution of the $\mathrm{NO}_{3}$ concentration and tritium level in groundwater are discussed below.

Compositional relations among dissolved species from the shallow and deep parts of the groundwater system can reveal the origin of solutes and the process that generated the observed water compositions (Lang et al. 2006). The diagrams of major chemical constituents in the Euphrates and groundwater samples were established (Fig. 3a-d).

The $\mathrm{Ca}^{2+}$ and $\mathrm{Mg}^{2+}$ ions are well correlated with $\mathrm{SO}_{4}{ }^{2-}$ $\left(R^{2}=0.92\right.$ and 0.79 , respectively) indicating that they most likely derive from the dissolution of sulfate in evaporite minerals. However, the majority of groundwater samples are located below line 1:1 indicating a deficit of $\mathrm{Ca}^{2+}$ and $\mathrm{Mg}^{2+}$ versus $\mathrm{SO}_{4}{ }^{2-}$ (Fig. 3a, b).

The depletion of $\mathrm{Ca}^{2+}$ and $\mathrm{Mg}^{2+}$ indicates the contribution of another geochemical process that affects cation content and may be related to the mechanism of basic exchanges, by which $\mathrm{Ca}^{2+}$ and $\mathrm{Mg}^{2+}$ are adsorbed on the surface of marl minerals and $\mathrm{Na}^{+}$is released to produce more saline water (Plummer et al. 1990). The computation of saturation indices (SI) calculated by geochemical code NETPATH 2.0 (Plummer et al. 1994) shows that saturation in gypsum (average $\mathrm{SI}$ of -0.05 ) increases with the $\mathrm{SO}_{4}{ }^{2-}$ concentration (Fig. 3c). The strong positive correlation between $\mathrm{Na}^{+}$and $\mathrm{Cl}^{-}$contents $\left(R^{2}=0.93\right)$ in groundwater samples in the Rasafeh area suggests a common origin for these ions and indicates the dissolution of evaporate deposits such as Halite ( $\mathrm{NaCl})$ (Magaritz et al. 1981) (Fig. 3d). The groundwater sample points are falling under line $1: 1$ and indicate an excess of $\mathrm{Na}^{+}$versus $\mathrm{Cl}$, which is balanced by $\mathrm{Ca}^{2+}$ and $\mathrm{Mg}^{2+}$.

In more saline groundwater samples, the reduction of $\mathrm{Ca}^{2+} / \mathrm{Na}^{+}$is typical of ion exchange, but the greater magnitude of $\mathrm{Na}^{+}$enrichment compared to the $\mathrm{Ca}^{2+}$ decline suggests an additional source of $\mathrm{Na}^{+}$. In this case, the sources could be related to dissolution of evaporate minerals, such as halite $(\mathrm{NaCl})$. Water from the shallow and deep wells was oversaturated with respect to calcite and dolomite (median 0.68 and 1.25, respectively) (Table 1). The higher dolomite saturation index for the groundwater flow system may indicate a longer residence time of water along groundwater flow paths or differences in aquifer mineralogy. Chemical variations in both shallow and deep wells are likely related to hydrologic and geochemical factors. For example, differences in water type $\left(\mathrm{Ca}-\mathrm{SO}_{4}\right.$ for the major part of groundwater and $\mathrm{Na}-\mathrm{Cl}$ for 
Fig. 3 Ions scatter plots of groundwater and surface water in the study area
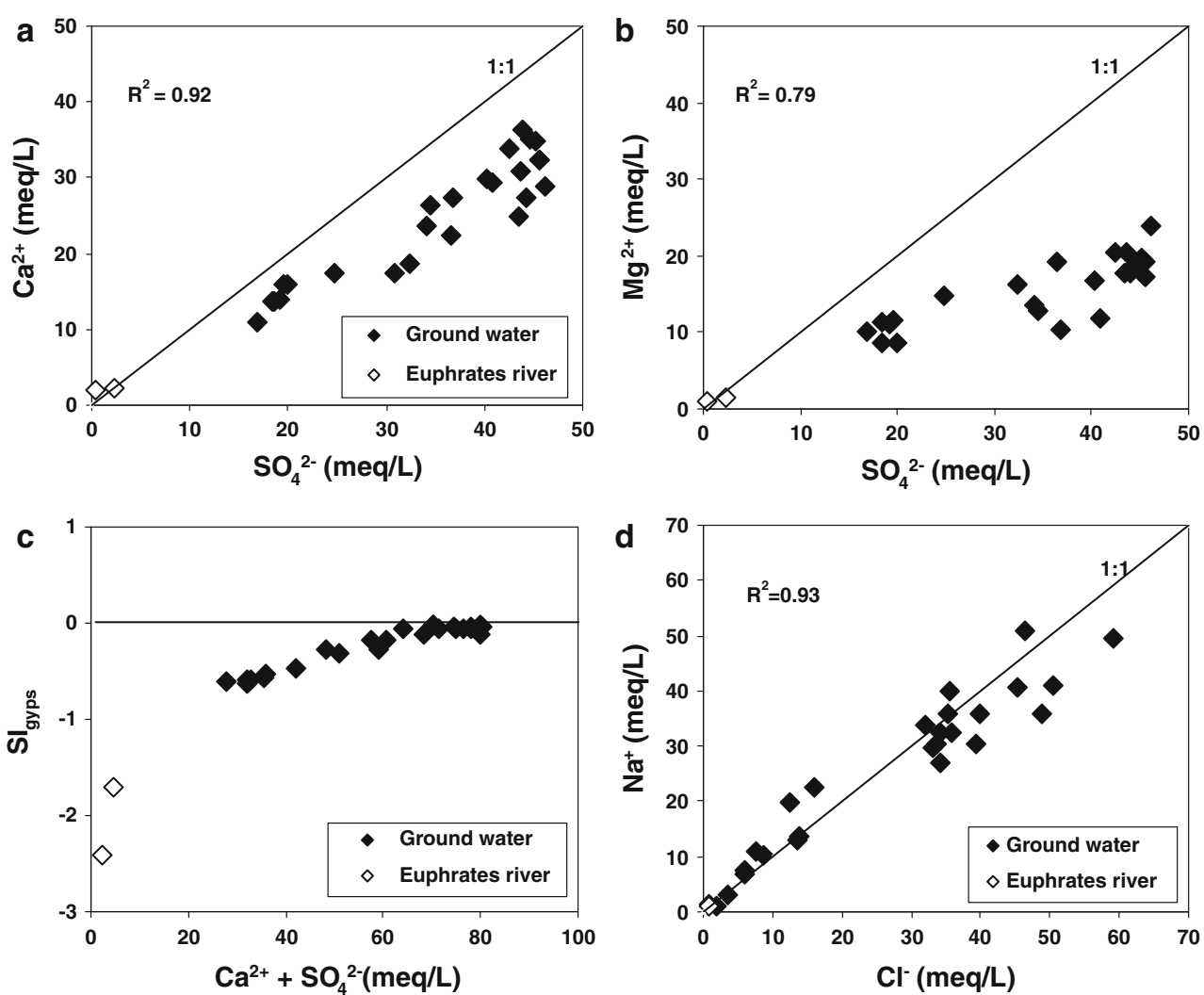

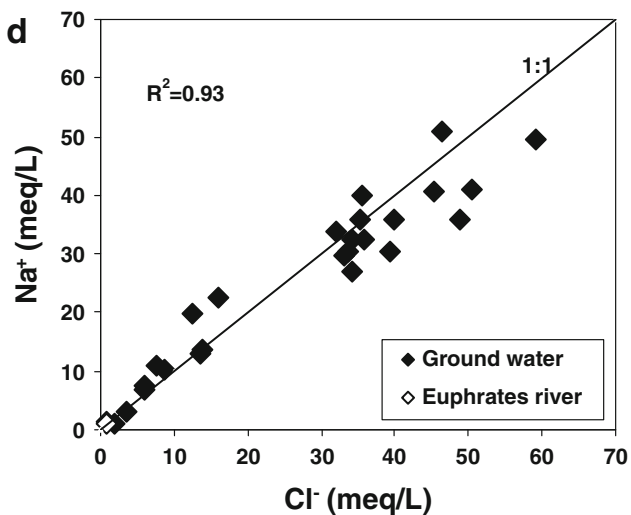

several deep wells), and higher values of dolomite saturation index, and $\mathrm{pH}$ in deep wells, indicate differences in aquifer mineralogy. The decrease in $\mathrm{HCO}_{3}{ }^{-}$is consistent with the loss of $\mathrm{CO}_{2}$ during recycling (Ó Dochartaigh et al. 2010), and therefore, a tendency toward calcite precipitation, supported by the positive correlation $\left(R^{2}=0.88\right)$ between $\mathrm{SI}_{\mathrm{cal}}$ and $\mathrm{pH}$.

The groundwater samples from wells located in the highly cultivated area (around the Rasafeh fault and Wadi, sites Nos. 13-25) reveal high $\mathrm{SO}_{4}{ }^{2-}, \mathrm{Cl}^{-}$, and $\mathrm{NO}_{3}{ }^{-}$ contents (averages of about 2,000, 1,400, and $100 \mathrm{mg} / \mathrm{L}$, respectively). This fact may be due to the influence of severe abstraction of groundwater in the area, leading to high drawdown which, in turn increases the hydraulic gradient and the inflow from the Euphrates River and dam reservoir. This assumption agrees with the pressure difference between the Euphrates and aquifer, which flows in the Rasafeh area under unconfined conditions along relatively short flow paths (Fig. 1).

\section{Stable isotope composition}

The relationship between $\delta^{18} \mathrm{O}$ and $\delta^{2} \mathrm{H}$ is illustrated in Fig. 4a, b. The $\delta^{18} \mathrm{O}$ and $\delta^{2} \mathrm{H}$ in the precipitation samples show great variation (from -12.31 to $+2.33 \%$ for $\delta^{18} \mathrm{O}$ and from -78.02 to $+6.63 \%$ for $\delta^{2} \mathrm{H}$, Fig. $4 \mathrm{a}$ ). The rainwater samples display a seasonal variation of isotopic composition, due the greater seasonal temperature variations (Clark and Fritz 1997; Al-Charideh and Abou Zakhem 2010). As often observed in arid climates, the light rainfall events are characterized by high ${ }^{18} \mathrm{O}$ and ${ }^{2} \mathrm{H}$ content, due to evaporation effect. However, these rainfalls do not significantly contribute to the effective recharge of groundwater (Gat 1987, 1991). Considering only heavier rainfall events $(>5 \mathrm{~mm}$ ), the Local Meteoric Water Line obtained in thermodynamic equilibrium conditions (slope of 8) is: $\delta^{2} \mathrm{H}=8 \delta^{18} \mathrm{O}+14 \%$.

This equation differs from that of the west Syrian meteoric line defined by Kattan (1997), in which the deuterium excess, defined by Dansgaard (1964) as $d=\delta^{2} \mathrm{H}-8 \delta^{18} \mathrm{O}$, was about $19 \%$. Monthly variation of $d$-excess show generally higher values in winter precipitation. The highest values (20-22\%) for an individual month were observed in January 2000 in two stations. This pattern can be attributed to the influence of Mediterranean air masses over the region during this month (Gat and Carmi 1970; Araguas-Araguas et al. 2000). The previous study of precipitation in Syria indicate that the greater influence of Mediterranean air masses is shown in the increase of $d$-excess values in costal mountains and south western part of Syria (e.g., around $19 \%$ ). However, the continental stations in the eastern part of the country show low $d$-excess values (e.g., $14 \%$ ). The lower $d$-excess values may be representing a maxing origin of air masses from Mediterranean Sea and a continental 

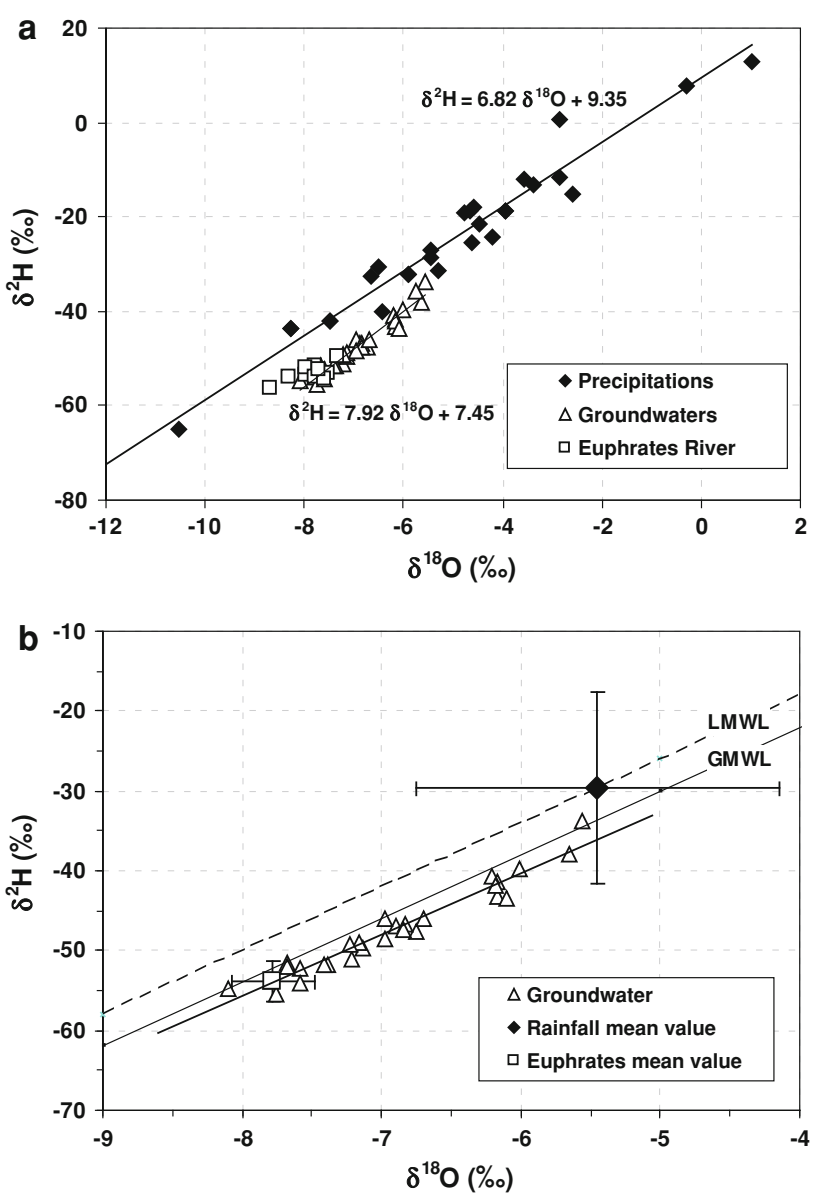

Fig. 4 a Isotopic plot of $\delta^{18} \mathrm{O}$ and $\delta^{2} \mathrm{H}$ values for rainwater, Euphrates River, and groundwater samples, and $\mathbf{b}$ Isotopic plot of $\delta^{18} \mathrm{O}$ and $\delta^{2} \mathrm{H}$ values showing the distribution of groundwater samples. The mean and standard deviation of the delta values of rainwater and Euphrates River samples are also shown

trajectory over the North African continent (Al-Charideh and Abou Zakhem 2010).

The mean values of $\delta^{18} \mathrm{O}$ and $\delta^{2} \mathrm{H}$ in five water samples from Euphrates dam reservoir (site No. 26) are $(-7.68 \pm 0.25 \%)$ and $(-51.90 \pm 1.46 \%)$, respectively, while the mean values of six water samples from the Euphrates River (site No. 5) are $-7.80 \pm 0.22 \%$ and $53.75 \pm 0.92 \%$, respectively. It can be observed that all the stable isotope values of surface water samples are more depleted with respect to those of local precipitation in the study area. This is due to the fact that the Euphrates River catchment is located at high altitude $(2,000-3,000 \mathrm{~m})$, and is fed by more depleted rainfall and snow melt.

The $\delta^{18} \mathrm{O}$ and $\delta^{2} \mathrm{H}$ composition of groundwater are ranged from -5.56 to $-8.1 \%$ and from -33.78 to $-54.7 \%$, respectively (Table 2 ). The relationship between $\delta^{2} \mathrm{H}$ and $\delta^{18} \mathrm{O}$ values for groundwater samples are defined by the following least squares regression equation (Fig. 4b): $\delta^{2} \mathrm{H}=7.9 \delta^{18} \mathrm{O}+7.45 \% \quad$ (with $\left.R^{2}=0.95\right)$.

Most of the samples are plot along the line parallel to the global meteoric water line (GMWL), given by $\delta^{2} \mathrm{H}=8$ $\delta^{18} \mathrm{O}+10 \%$ (Craig 1961). This suggests that there has been minor evaporative fractionation, consistent with the evidence demonstrated by the groundwater chemistry. Any evaporation may take place before the precipitation reaches ground surface.

The staple isotope composition of groundwater in the Rasafeh area are significantly more depleted than the present-day precipitation, while generally remaining relatively higher than those of Euphrates River (excluding the sample No. 11). This isotopic difference between precipitation and groundwater, which cannot be explained by an altitude effect or by evaporation, may result from the mixing of Euphrates River and groundwater in the Rasafeh area.

The difference of hydraulic head between the Euphrates River and the aquifers system with severe exploitation of the groundwater, favors flow leakage from Euphrates River. Thus, the isotopic composition of groundwater would represent a mixing between present precipitation recharge and Euphrates River. The recharge from irrigation return flow is also expected. From isotopic balance equations, it is possible to estimate the contribution of Euphrates River to this mixing according to the following equation (Plummer et al. 1998):

$\delta^{18} \mathrm{O}_{\mathrm{GW}}=X \delta^{18} \mathrm{O}_{\text {Euph }}+(1-X) \delta^{18} \mathrm{O}_{\mathrm{Pre}}$

where $X$ and $(1-X)$ are the fractions of recharge contribution to groundwater, from the Euphrates River and precipitation, respectively. The $\delta^{18} \mathrm{O}_{\mathrm{GW}}, \delta^{18} \mathrm{O}_{\text {Euph }}$, and $\delta^{18} \mathrm{O}_{\text {Pre }}$ are respectively the ${ }^{18} \mathrm{O}$ contents of groundwater, Euphrates River, and precipitation.

The mean values of -7.71 and $-52.5 \%$ were adopted for ${ }^{18} \mathrm{O}$ and $\delta^{2} \mathrm{H}$ of Euphrates River, whereas the weighted mean values $\left(\delta^{18} \mathrm{O}=-5.41 \%\right.$ and $\delta^{2} \mathrm{H}=-27.55 \%$ o) were used for precipitation, which correspond to the rainfall events above $5 \mathrm{~mm}$.

The isotope balances show that the contribution of the Euphrates River may be very high in the majority of wells and range from 30 to $95 \%$. The high values of recharge rate (more than $70 \%$ ) were observed in the Quaternary aquifer of the Euphrates valley and in the Miocene aquifer around the Rasafeh fault system. The relative contributions of diffused recharge from precipitation are very high for wells located at the edge of Al-bashari Mountain.

Some differences between the ${ }^{18} \mathrm{O}$ and ${ }^{2} \mathrm{H}$ balances show that the representative points of groundwater are not on a pure mixing line between precipitation and Euphrates water. Isotope content is controlled not only by a mixing phenomenon but also two other processes should be taken 
Table 2 Isotopic composition values of groundwater and surface water samples in the study area

\begin{tabular}{|c|c|c|c|c|c|c|c|}
\hline Map (no.) & Long. (E) & Lat. (N) & $\delta^{18} \mathrm{O}(\% \mathrm{o})$ & $\delta^{2} \mathrm{H}(\% 0)$ & ${ }^{3} \mathrm{H}(\mathrm{TU})$ & $\delta^{13} \mathrm{C}(\%)$ & ${ }^{14} \mathrm{C}(\%)$ \\
\hline 1 & 39.12 .54 & 35.34 .02 & -5.56 & -33.78 & 9.0 & -2.19 & 111.5 \\
\hline 2 & 39.23 .49 & 35.46 .40 & -7.22 & -50.98 & 15.2 & & \\
\hline 3 & 39.06 .33 & 35.37 .37 & -6.17 & -41.49 & 3.5 & -2.29 & 76.4 \\
\hline 4 & 39.11 .37 & 35.45 .52 & -6.90 & -46.81 & 19.3 & & \\
\hline 5 (ER) & 39.12 .17 & 35.50 .43 & -7.80 & -53.87 & 8.1 & & \\
\hline 6 & 39.05 .09 & 35.52 .12 & -7.76 & -55.39 & 15.9 & & \\
\hline 7 & 39.01 .24 & 35.52 .55 & -7.68 & -51.60 & 12.4 & & \\
\hline 8 & 39.00 .09 & 35.53 .54 & -7.58 & -52.28 & 10.3 & -10.77 & 112.2 \\
\hline 9 & 38.54 .45 & 35.50 .47 & -6.97 & -46.10 & 0.9 & -10.80 & 101.6 \\
\hline 10 & 38.58 .17 & 35.45 .57 & -7.13 & -49.62 & 1.7 & -2.42 & 104.9 \\
\hline 11 & 38.55 .33 & 35.38 .03 & -8.10 & -54.73 & 1.2 & -7.23 & 103.7 \\
\hline 12 & 38.53 .05 & 35.29 .02 & -7.38 & -51.69 & 2.3 & -10.93 & 94.2 \\
\hline 13 & 38.46 .09 & 35.33 .05 & -7.41 & -51.69 & 1.1 & & \\
\hline 14 & 38.45 .44 & 35.35 .02 & -7.16 & -48.92 & 2.6 & -4.36 & 117.4 \\
\hline 15 & 38.45 .32 & 35.36 .06 & -6.75 & -47.62 & 2.3 & -3.15 & 97.5 \\
\hline 16 & 38.45 .33 & 35.38 .22 & -6.83 & -46.78 & 15.0 & -11.38 & 124.8 \\
\hline 17 & 38.46 .24 & 35.44 .59 & -6.17 & -43.18 & 6.7 & & \\
\hline 18 & 38.46 .20 & 35.47 .15 & -5.65 & -38.00 & 5.1 & & \\
\hline 19 & 38.46 .58 & 35.50 .49 & -6.85 & -47.49 & 3.5 & -2.03 & 77.9 \\
\hline 20 & 38.49 .46 & 35.50 .12 & -6.70 & -46.10 & 3.7 & & \\
\hline 21 & 38.40 .55 & 35.47 .22 & -6.01 & -39.70 & 3.5 & & \\
\hline 22 & 38.41 .49 & 35.28 .31 & -6.97 & -48.54 & 2.7 & -5.30 & 105.3 \\
\hline 23 & 38.33 .38 & 35.33 .40 & -6.18 & -41.91 & 2.5 & -4.74 & 128.4 \\
\hline 24 & 38.39 .20 & 35.37 .49 & -6.10 & -43.44 & 0.8 & -6.15 & 91.7 \\
\hline 25 & 38.32 .50 & 35.50 .53 & -7.58 & -54.14 & 10.2 & -8.16 & 106.7 \\
\hline 26 (ED) & 38.34 .10 & 35.53 .30 & -7.68 & -51.90 & 10.6 & & \\
\hline 27 & 38.28 .23 & 35.27 .57 & -7.23 & -49.24 & 0.9 & -5.57 & 110.2 \\
\hline
\end{tabular}

ER Euphrates River, ED Euphrates dam

into account: evaporation of irrigated water (no isotope data are available), which may occur during infiltration, and locally a possible contribution from deep groundwater. The effect of these two phenomena on isotope balances are similar, since the intervention of either of them leads to underestimate the Euphrates River contribution, in particular when ${ }^{18} \mathrm{O}$ data are considered.

Tritium and ${ }^{14} \mathrm{C}$ values and mean residence time

Tritium is naturally produced in the upper atmosphere by the bombardment of nitrogen with fast neutrons from cosmic rays. However, after the aboveground nuclear tests, the tritium concentration in precipitation abruptly increased, reaching a maximum in 1963. As a result, the tritium values increased dramatically reaching a peak of several hundred TU during the mid-1960s, followed by a sharp decline after the nuclear testing moratorium. Tritium is an ideal tracer of groundwater since it is a part of the water molecule. However, tritium is a relatively short-lived radioisotope
(12.4 years half life) and thus, it can be used to detect recent recharge and to estimate the residence time of young groundwater recharged during the last 60 years (McConnell and Michel 1998; Beyerle et al. 1999). For many recent hydrogeological investigations, including this one, groundwater age can be estimated qualitatively from the ${ }^{3} \mathrm{H}$ activity values: $<0.8 \mathrm{TU}$ corresponds to sub-modern water ( $<1950$ s); from 0.8 to 4 TU corresponds to a mixture of submodern and modern water; 5-15 TU corresponds to modern water $(<5-10$ year old); from 15 to 30 TU corresponds to water with containing some ${ }^{3} \mathrm{H}$ produced by nuclear testing (1980s to early-mid 1990s); >30 TU corresponds to water with high content of ${ }^{3} \mathrm{H}$ coming from nuclear weapons testing (1960s-1970s) (Clark and Fritz 1997; Motzer 2007).

The tritium content in the precipitation collected during the period 1998-1999 at the Ar-Raqqa and Palmyra meteoric stations had an average value of 7.3 TU (weighted mean of 14 samples) and varied from 4.2 to 9.8 TU, while the tritium content in the Euphrates River had an 
average of $10.8 \mathrm{TU}$ (mean of 10 samples) and varied from 9.9 to $11.8 \mathrm{TU}$.

Tritium activities of the 25 groundwater samples ranged from 0.8 to $19.5 \mathrm{TU}$ (Table 2). Tritium activities indicating the oldest water occurred in 5 of the 25 samples and were always in the deepest wells. In shallow wells, the tritium concentrations range from 10 to $19.3 \mathrm{TU}$ and from 0.8 to 6.7 TU in deep wells (Fig. 5a). The high tritium content (9 TU) detected in well No. 1 suggests the rapid recharge (fast diffuse infiltration process) of the recent precipitation to the groundwater throughout carbonate Al-beshri Mountain (Fig. 1).

The similarity of ${ }^{3} \mathrm{H}$ concentrations in groundwater and surface water, indicates that Euphrates River recharges the shallow groundwater system and moves through the quaternary deposits very rapidly, $<10$ years for parts of the shallow flow system and $<30$ years for the deepest parts of the aquifer. Therefore, based on high tritium concentrations (Table 2), sampled waters from the Rasafeh aquifer is of relatively recent origin, and almost certainly during the period of the falling limb of the tritium transient (post1963).

In order to confirm the assumptions concerning recent recharge water, in particular under the influence of certain pumping, the measurements of carbon-14 activity in dissolved carbonates have been carried out, in particular for water with low tritium level.

Radiocarbon activity and the results of ${ }^{13} \mathrm{C}$ content are reported in Table 2. The ${ }^{14} \mathrm{C}$ in 15 groundwater samples range between 76 and $128 \mathrm{pmc}$ and $\delta^{13} \mathrm{C}$ increases from -11.38 to $-2.19 \%$. Most samples with ${ }^{14} \mathrm{C}$ activities higher than 100 pmc were measured along the Rasafeh fault system in both shallow and deep aquifer units (Fig. 5c). These high values may be due to exchange with modern soil $\mathrm{CO}_{2}$ specifically in the agriculturally used areas. The presence of high tritium and high ${ }^{14} \mathrm{C}$ activities in both shallow and deep wells suggested mixing of young and older groundwater. The younger groundwater was likely introduced into the respective groundwater systems from pumping activities. Alternatively, as many bedrock wells are completed as open holes, the intersection of a fracture recharged by modern water may have contributed modern water to the bedrock wells.

In summary, based on carbon isotope data, it is not necessary to make detailed correction for the radiocarbon age of groundwater. Therefore, the high ${ }^{14} \mathrm{C}$ values can prove that the groundwater in the Rasafeh area is of recent age. This finding agrees, in fact, with the relatively high tritium content, which normally can be taken as a strong and realistic indicator for recent age of groundwater. Furthermore, it can be concluded, as a result of bilateral mixing with Euphrates River water that the groundwaters are renewable.

\section{Nitrate content}

The presence of high nitrate associated with high tritium and ${ }^{14} \mathrm{C}$ activities in both shallow and deep aquifer units indicate that groundwater are highly susceptible to anthropogenic contamination (Figs. 5, 6). Nitrate, tritium, and ${ }^{14} \mathrm{C}$ data against depth were plotted in Fig. 5. The similar distribution of nitrate and tritium data with depth indicates the increasing vulnerability risk for both shallow and deep aquifer units around the Rasafeh fault system

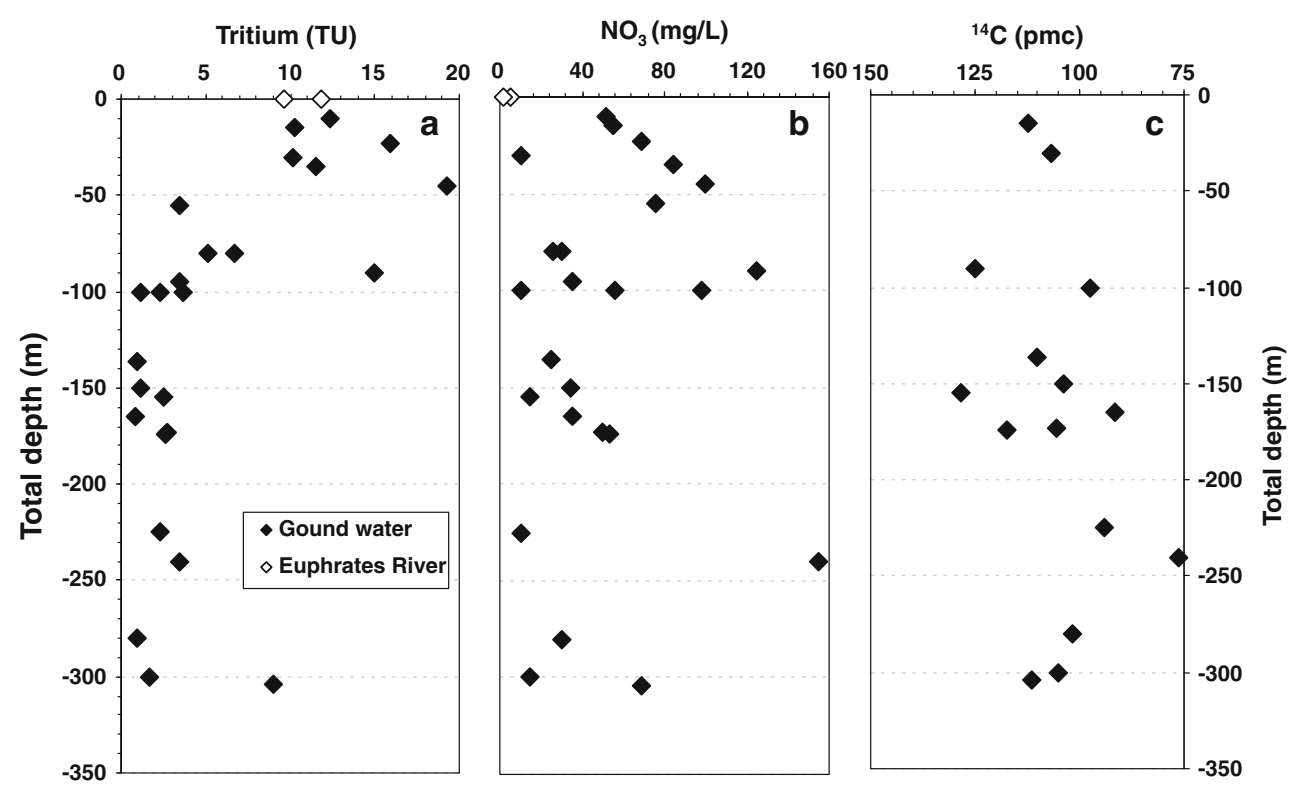

Fig. 5 a Distribution of tritium, $\mathrm{NO}_{3}(\mathbf{b})$, and ${ }^{14} \mathrm{C}(\mathbf{c})$ values with depth (meters below land surface) 
Fig. 6 a Relationship between ${ }^{3} \mathrm{H}$ and $\mathrm{NO}_{3}$ and, $\mathbf{b}$ the relationship between ${ }^{14} \mathrm{C}$ and $\mathrm{NO}_{3}$ in groundwater samples in the study area
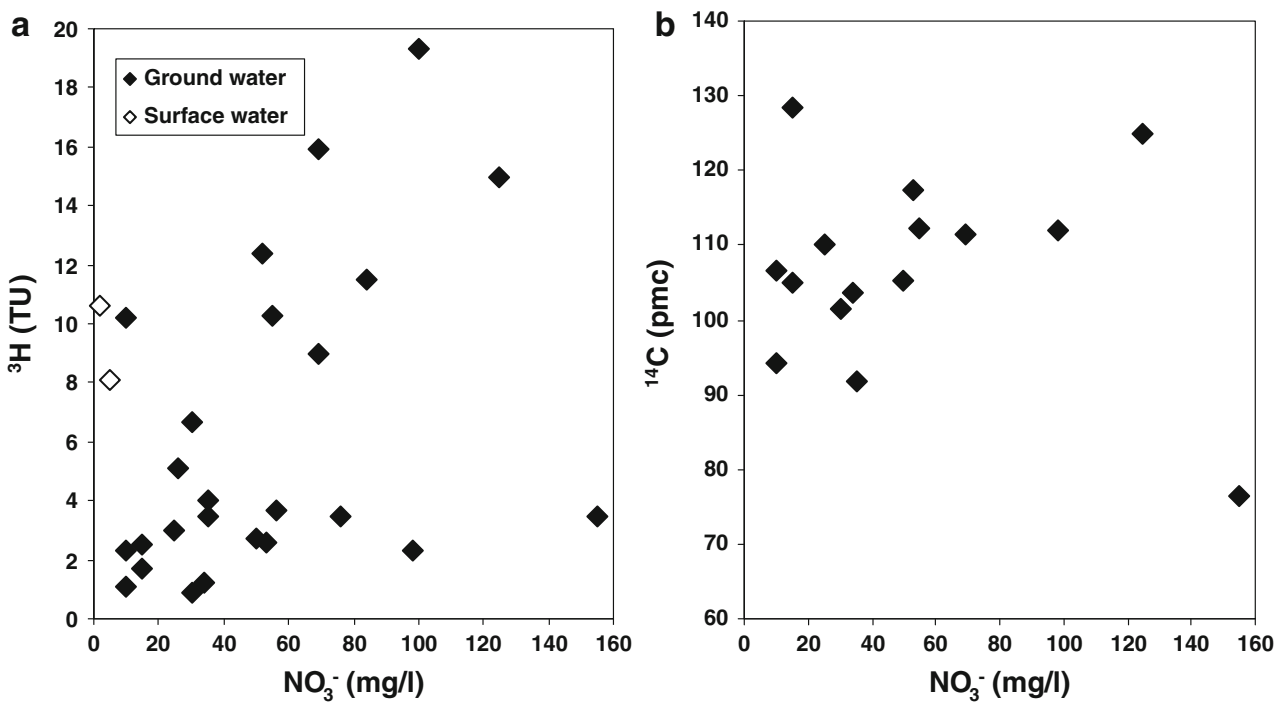

which controls the natural recharge in the study area. On the other hand, there is a significant positive correlation between nitrate, tritium, and ${ }^{14} \mathrm{C}$ values (Fig. 6a, b). The nitrate values increase with radiocarbon activities. This positive correlation is caused by both natural recharge and irrigation return flow because these processes not only modify the water quality but also change radiocarbon activities mainly due to exchange with modern soil $\mathrm{CO}_{2}$ in the agriculturally used areas.

Data of $\mathrm{NO}_{3}$ concentration in groundwater were not available prior to the construction of Euphrates dam reservoir at the end of 1978. Consequently, after this period, major change in chemical groundwater composition has been critical in revealing change of recharge processes at the arid Rasafeh area. The agricultural influence is reflected in nitrate concentrations. The nitrate in groundwater reaches values up to $50 \mathrm{mg} / \mathrm{L}$, although two wells show exceptionally high contents $(155 \mathrm{mg} / \mathrm{L}$ in well 3 and $125 \mathrm{mg} / \mathrm{L}$ in well 16).

In terms of groundwater resources management with respect to the high $\mathrm{NO}_{3}$ levels, the age of groundwater is an important parameter. If the age of groundwater is well estimated, then the concentration of nitrate could be related to the groundwater level of fertilizer application of the particular time of recharge suggested relatively recent recharge, but with the possibility of mixing with older groundwater (Robertson and Cherry 1992).

In order to judge this statement, the spatial distribution of $\mathrm{NO}_{3}$ and tritium concentration is shown (Fig. 7). The distribution indicates the natural recharge regions. Higher values demonstrate shorter residence times and consequently potentially greater recharge. High concentrations of nitrate, often over $50 \mathrm{mg} / \mathrm{L}$, associated with high tritium level are characteristic of areas of arable farming around the Rasafeh fault system, and suggest the importance of irrigated return flow on the groundwater recharge, while low concentrations for both tritium and nitrate are generally found east of the Rasafeh area fault system and suggest the control by the hydrological properties and geometry of the aquifers.
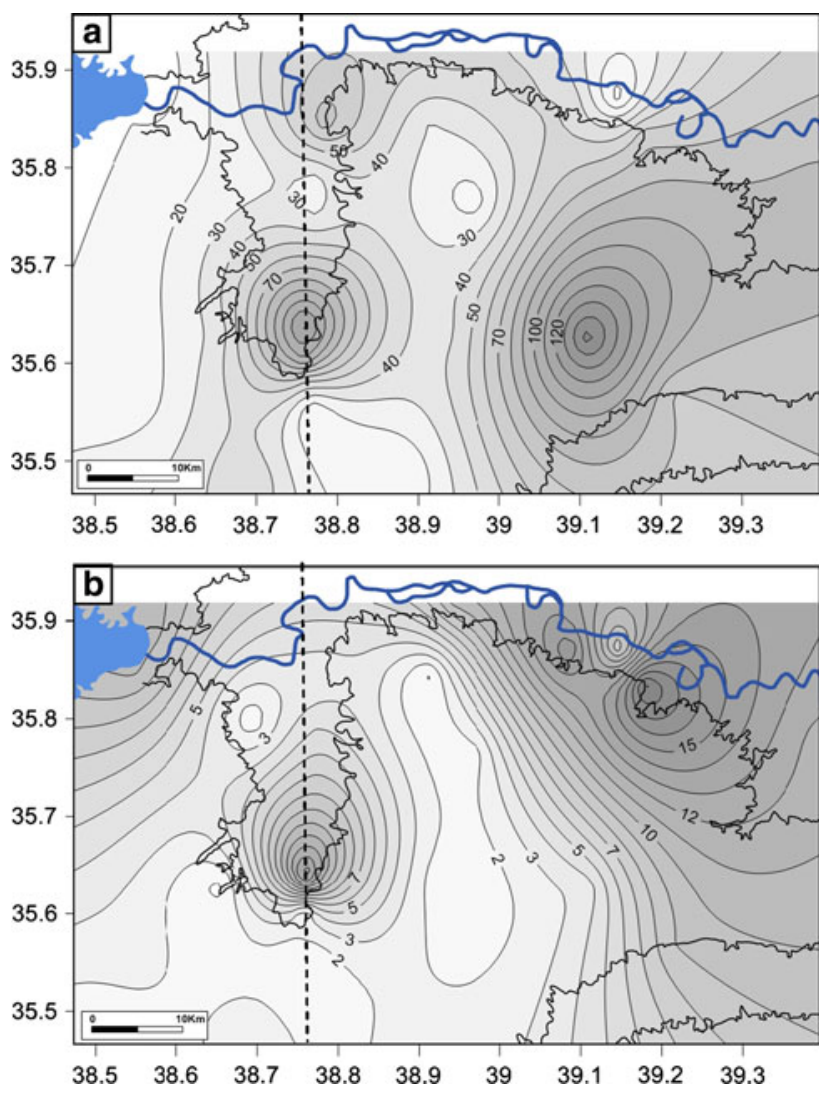

Fig. 7 a Spatial distribution of the $\mathrm{NO}_{3}$ concentration and, b Spatial distribution of the tritium content in the groundwater and surface water samples in the study area 
In reality, such values are probably the consequence of mixing between more recent waters of the shallow pathway and groundwater of the deepest circuit, in the wells located south east of the study area where the contribution of recharge related to the fast infiltration floods.

\section{Conclusion}

The hydrochemical and isotopic investigations of surface water and groundwater in the arid Rasafeh area in the northeastern part of Syria has aided to improve the knowledge about the surface water and groundwater dynamic and the interactions between different natural and anthropogenic factors, which is important for a sustainable water resource management in arid zones.

The geological and hydrogeological settings show that the Euphrates River feed the major aquifers in the Quaternary and Middle Miocene rocks. Such interconnection could take place directly by the differences in head between the Euphrates dam reservoir and groundwater. In addition, the tectonic factor through fracture zones such as the Rasafeh fault has an important role to facilitate this connection.

Thermodynamic calculation reveals that the dissolution of evaporate mineral is the main factor of high salinity, and the salinity amount is basically related to $\mathrm{SO}_{4}{ }^{2-}$ from gypsum dissolution. Moreover, the study of the isotopic composition $\left(\delta^{18} \mathrm{O}\right.$ and $\left.\delta^{2} \mathrm{H}\right)$ of groundwater in the Rasafeh area made it possible to show a surface water contribution from the Euphrates River to the aquifers. This contribution, quantified by isotope mass balances, is very variable and can sometimes reach $100 \%$.

The presence of high activity of tritium and radiocarbon in the groundwater confirms that the groundwater resources in the study area are of recent age and are highly susceptible to anthropogenic contamination. A good correspondence is observed between the spatial distributions of tritium and nitrate concentrations around the Rasafeh fault system. This shows that the spatial distribution of the contamination is essentially linked to the presence of a dynamic flow system prevailing in this area, more precisely to groundwater age and the important role of irrigated return flow on the groundwater recharge. It is recommended in the future investigations to use of $\mathrm{CFC} /$ tritium technique to refine the age and improve conceptual models of the groundwater flow systems in the arid Rasafeh area.

Acknowledgments The authors would like to thank Prof. I. Othman, Director General of AECS for use of their facilities during this study. Many thanks are also due to W. Agha Rasoul, S. Rammah, and Z. Kattan for their helpful comments and useful discussion. The authors are grateful to the staff of PINSTECH isotope laboratory of
Pakistan, and the staff laboratory of AECS for their cooperation in performing the isotopic and chemical analyses.

Open Access This article is distributed under the terms of the Creative Commons Attribution License which permits any use, distribution, and reproduction in any medium, provided the original author(s) and the source are credited.

\section{References}

Aggarwal PK, Froehlich K, Gonfiantini R, Gat JR (2005) Isotope hydrology: a historical perspective from the IAEA. In: Aggarwal PK, Gat JR, Froehlich K (eds) Isotopes in the water cycle: past, present and future of a developing science. Springer, Berlin, p 381

Al-Charideh A, Abou Zakhem B (2010) Distribution of tritium and stable isotopes in precipitation in Syria. Hydrol Sci J 55(5):1-13

Araguas-Araguas L, Froehlich K, Rozanski K (2000) Deuterium and oxygen-18 isotope composition of precipitation and atmospheric moisture. Hydrol Process 14:1341-1355

Beyerle U, Aeschbach-Hertig W, Hofer M, Imboden DM, Baur H, Kipfer R (1999) Infiltration of river water to a shallow aquifer investigated with ${ }^{3} \mathrm{H} /{ }^{3} \mathrm{He}$, noble gases and CFCs. J Hydrol 220:169-185

Clark I, Fritz P (1997) Environmental isotopes in hydrology. Lewis, Boca Raton, p 345

Cook PG, Herczeg AL (1999) Environmental tracers in subsurface hydrology. Kluwer, Boston, p 552

Craig H (1957) Isotopic standards for carbon and oxygen and correction factors mass-spectrometric analysis of carbon dioxide. Geochim Cosmochim Acta 12:133-149

Craig H (1961) Isotopic variations in meteoric water. Science 133(3465):1702-1703

Dansgaard W (1964) Stable isotopes in precipitation. Tellus 16:436

Florkowski T (1981) Low-level tritium assay in water samples by electrolytic enrichment and liquid-scintillation counting in the IAEA laboratory. In: Proceedings of the international symposium on methods of low-level counting and spectrometry. International Atomic Energy Agency, Vienna, p 558

Gat JR (1987) Variability (in time) of the isotopic composition of precipitation: consequences regarding the isotopic composition of hydrologic systems. In: Isotope techniques in water resource development, IAEA-SM-319/39. IAEA, Vienna, pp 551-563

Gat JR (1991) Monitoring the response of arid zone hydrology to environmental change by means of the stable isotope composition of groundwaters. In: Isotope techniques in water resource development, IAEA-SM-319/39. IAEA, Vienna, pp 521-532

Gat JR, Carmi I (1970) Evolution of the isotopic composition of atmospheric waters in the Mediterranean Sea area. J Geophys Res 75:3039-3048

Gersar-Sect (1977) Development of the lower Euphrates valley. Technical report zone 1. Ministry of irrigation, Syrian Arab Republic, p 266

Gonfiantini R (1978) Standard for stable isotope measurements in natural compounds. Nature 271:534-536

Herczeg AL, Leaney FW (2010) Review: environmental tracers in arid-zone hydrology. Hydrog J. doi:10.1007/s10040-010-0652-7

Japan International Cooperation Agency (JICA) (1997) The study on water resources development in the northwestern and central basin in the Syrian Arab Republic. Final report, Damascus, Syria

Jolly ID, McEwan KL, Holland KL (2008) A review of groundwatersurface water interactions in arid/semi-arid wetlands and the 
consequences of salinity for wetland ecology. Ecohydrology $1: 43-58$

Kattan Z (1997) Chemical and environmental isotope study of precipitation in Syria. J Arid Environ 35:601-615

Lang YC, Liu CQ, Zhao ZQ, Li SL, Han GL (2006) Geochemistry of surface and groundwater in Guiyang, China: water/rock interaction and pollution in a karst hydrological system. Appl Geochem 21:887-903

Magaritz M, Nadler A, Koyumdjisky H, Dan N (1981) The use of Na/ $\mathrm{Cl}$ ratio to trace solute sources in semiarid zone. Water Resour Res 17:602-608

McConnell JB, Michel RL (1998) Flow of river water into a karstic limestone aquifer. Part 2. Dating the young fraction in groundwater mixtures in the Upper Floridan aquifer near Valdosta, Georgia. Appl Geochem 8:1017-1043

Mook WG (2006) Introduction to isotope hydrology: stable and radioactive isotopes of hydrogen, oxygen and carbon. Taylor \& Francis Group, London, p 226

Motzer WE (2007) Tritium age dating of groundwater. In: HydroVisions, vol 16. Groundwater Resources Association of California

Ó Dochartaigh BE, MacDonald AM, Darling WG, Hughes AG, Li JX, Shi LA (2010) Determining groundwater degradation from irrigation in desert-marginal northern China. Hydrol J 18:1939_ 1952

Plummer LN, Busby JF, Lee RW, Hanshaw BB (1990) Geochemical modeling of the Madison aquifer in part of Montana, Wyoming and South Dakota. Water Resour Res 26:1981-2014

Plummer LN, Perstemon EC, Parkhurst DL (1994) An interactive code (NETPATH) for modeling NET geochemical reaction along a flow PATH-version 2.0: US Geological Survey Water Resources Investigations Report 94-4169

Plummer LN, Busenberg E, Drenkard S, Schlosser P, Ekwurzel B, Weppernig R, McConnell JB, Michel RL (1998) Flow of river water into a karstic limestone aquifer. 2. Dating the young fraction in groundwater mixtures in the Upper Floridan aquifer near Valdosta, Georgia. Appl Geochem 13:1017-1043

Popov OV (1979) The interaction of surface- and groundwater in the hydrological cycle. J Hydrol Sci 6:3-4

Popov OV, Sokolov BL (1986) Quantitative assessment of interaction between surface water and groundwater. In: Proceedings of the Budapest symposium on conjunctive water use. IAHS publication no. 156

Robertson WD, Cherry JA (1992) Hydrogeology of an unconfined sand aquifer and its effect on the behavior of nitrogen from a large-flux septic system. Appl Hydrogeol 1:33-43

Smith RL, Howes BL, Duff JH (1991) Denitrification in nitratecontaminated groundwater: occurrence in steep vertical geochemical gradients. Geochim Cosmochim Acta 55:1815-1822

Sophocleous M (2002) Interactions between groundwater and surface water: the state of the science. Hydrol J 10:52-67

Tamers MA, Scharpensel HW (1970) Sequential sampling of radiocarbon in groundwater. Isotope hydrology. IAEA, Vienna, pp 241-256

UNDP-FAO (1966) Etudes des Ressources en Eaux Souterraines (République Arabe Syrienne). Rapport Final, FAO/SF:17/SYR, p 267

UNDP-FAO (1977) Survey of the Balikh basin. Technical report on hydrogeological investigations and drainage studies. Ministry of irrigation, Syrian Arab Republic, p 65

Wassenaar L (1995) Evaluation of the origin and fate of nitrate in the Abbotsford Aquifer using the isotopes of ${ }^{15} \mathrm{~N}$ and ${ }^{18} \mathrm{O}_{\text {in }} \mathrm{NO}_{3}{ }^{-}$. Appl Geochem 10:391-405

Winter TC, Harvey JW, Franke OL, Alley WM (1998) Groundwater and surface water a single resource. US Geological Survey Circular 1139, Denver, Colorado 